\title{
INTERNATIONALIZATION AND INTRAPRENEURSHIP IN ENTREPERENEURIAL ACTIVITIES OF ENTERPRISES OF THE EUROPEAN UNION - THE EMPIRICAL RESEARCH
}

\author{
Helena Kościelniak \\ Czestochowa University of Technology
}

\begin{abstract}
The aim of the paper is to present the scope of internationalization and intrapreneurship of enterprises in the EU and to assess the position of Polish enterprises in this field. To achieve the intended objective there are presented the analytical approaches to entrepreneurship (selected issues) and there are introduced the results of the empirical research based on the report - Global Entrepreneurship Monitor 2012-2014 and the own research of 2016. The value of the paper consists in drawing comparisons in the global perspective as well as comparisons between individual countries in the discussed area whose complementation are the fragmentary results of the research into intrapreneurship, the motive of opportunity and necessity of the enterprises of the Silesian Voivodeship.
\end{abstract}

Keywords: entrepreneurship, internationalization, intrapreneurship

DOI: $10.17512 /$ znpcz.2016.3.1.07

\section{Around the analytical approach to entrepreneurship (selected issues)}

A.K. Koźmiński (Koźmiński 2004, p. 245-246) indicates six basic functions of entrepreneurship which include:

- intensive use of resources, particularly unlimited ones, i.e. knowledge and human capital;

- rapidity of response to market signals enabling the identification of new opportunities and mobilization of resources;

- flexibility of response to market signals (buyers' market);

- creating and testing innovation, i.e. completely new objects or services;

- protective buffer, protection of important sectors and large enterprises from disasters;

- blurring the boundaries between organizations and the environment, many functions of the enterprise of lower value added, not requiring the involvement of core competencies is the object of activities of independent enterprises.

Entrepreneurship, perceived as a specific mode of action, requires the observation of such rules as: absorptivity and openness of organizations to innovation, systematic measurement of effectiveness of implemented innovation, undertaking some specific actions concerning organizational structure, staffing, principles of management of teams of employees, wage system, reward system, avoiding doing 
things which are not allowed in business management. In the area of the phenomena of entrepreneurship, there are, among others, such phenomena as: entrepreneurial attitudes, entrepreneurial attitudes of women and men, social conditions for development of entrepreneurship, motives of setting up a business activity, motivation of women and men, entrepreneurship of young people, level of entrepreneurship, internationalization and intrapreneurship. In the modelling of the entrepreneurial process of GEM (Global Entrepreneurship Monitor), there are identified three stages of development of a business activity: nascent entrepreneurs, new businesses and established ones. In the process of entrepreneurship, GEM also indicates the attitude and abilities preceding the decision on starting a business as well as the reasons for abandoning the activity by former entrepreneurs.

Business analytics is extended by the progression of networking of the economy and business. The network is the set of measures (infrastructure) and principles (infostructure) allowing entities that have access to them to take and implement joint projects provided that such measures are appropriate to their needs and are suitable to be used together (infoculture) by the network (Bressand, Distler 1955; Czakon 2012, p. 46; Niemczyk, Stańczyk-Hugiet, Jasińska 2012, p. 108; Ziółkowska 2013, p. 38-40).

Table 1. A network typology for understanding general network characteristics and intersections

\begin{tabular}{|c|c|c|c|}
\hline \multicolumn{4}{|l|}{ Network typology } \\
\hline $\begin{array}{l}\text { Social networks: } \\
\text { individuals, family, friends, } \\
\text { acquaintances, colleagues, } \\
\text { employees, etc. }\end{array}$ & $\begin{array}{l}\text { Business } \\
\text { suppliers, } \\
\text { strategic p } \\
\text { customers } \\
\text { etc. }\end{array}$ & $\begin{array}{l}\text { Norks: } \\
\text { tpetitors, } \\
\text { lers, } \\
\text { areholders }\end{array}$ & $\begin{array}{l}\text { Institutional networks: gov- } \\
\text { ernment, NGOs, business incu- } \\
\text { bators, research institutes, } \\
\text { agencies for international } \\
\text { development, advisory } \\
\text { \& support offices, etc. }\end{array}$ \\
\hline \multicolumn{2}{|c|}{ Intra- \& inter-organizational networks } & \multicolumn{2}{|c|}{ Inter-organizational \&strategic networks } \\
\hline
\end{tabular}

Source: Own study based on (Oparaocha 2015, p. 861-873)

In Table 1, institutional networks represent the network relationships that can exist between a firm and publically funded, open-access institutions. In our understanding, one of the aims of institutional networks is to provide support functions and create an atmosphere that can foster cross-border investment and improve business success, both locally and internationally.

\section{The assessment of internationalization and intrapreneurship of the activities of enterprises in Poland and the EU in the light of the conducted research}

For the purposes of the empirical research in the field of entrepreneurship in the GEM Model (Global Entrepreneurship Monitor - Poland 2014), to determine the relationship between the extent of internationalization and the stage of enterprise development, there were used four variables; they are the measure of the percentage 
of customers from outside the specific country per entrepreneurs at the early stage of development - TEA (Total Early-Stage Entrepreneurial Activity). In the group of the quantified variables there are:

- non-exporters, i.e. enterprises at the early stage of TEA that do not have customers outside their home country;

- small-scale exporters, i.e. entrepreneurs at the early stage of TEA that have $1 \%$ $-25 \%$ of customers outside their home country;

- medium-scale exporters, i.e. entrepreneurs at the early stage of TEA that have $25 \%-75 \%$ of customers outside their home country;

- established exporters, i.e. entrepreneurs at the early stage of TEA that have $75 \%$ $-100 \%$ of customers outside their home country (see Table 2).

Table 2. The evaluation variables of internationalization of enterprises taking into account the percentage of customers outside the home country

\begin{tabular}{|l|l|l|}
\hline No. & Specification & $\%$ of customers outside the home country \\
\hline 1. & Non-exporters & 0 \\
\hline 2. & Small-scale exporters & $1-25$ \\
\hline 3. & Medium-scale exporters & $26-75$ \\
\hline 4. & Established exporters & $76-100$ \\
\hline
\end{tabular}

Source: Own study based on (GEM 2015, p. 31-32)

The empirical research for 2014 indicates that the differences in the degree of internationalization of individual countries are deepening.

Table 3. The level of internationalization of enterprises in Europe (\% TEA) in years 2013-2014

\begin{tabular}{|l|l|l|l|l|l|l|l|l|l|}
\hline \multirow{2}{*}{ No. } & \multirow{2}{*}{$\begin{array}{l}\text { Country } \\
\end{array}$} & $\begin{array}{l}\text { Non- } \\
\text { exporters }\end{array}$ & \multicolumn{2}{l|}{$\begin{array}{l}\text { Small-scale } \\
\text { exporters }\end{array}$} & \multicolumn{2}{l}{$\begin{array}{l}\text { Medium-scale } \\
\text { exporters }\end{array}$} & \multicolumn{2}{l}{$\begin{array}{l}\text { Established } \\
\text { exporters }\end{array}$} \\
\cline { 2 - 11 } 1. & 2013 & 2014 & 2013 & 2014 & 2013 & 2014 & 2013 & 2014 \\
\hline 2ountries oriented to & 68.06 & 76.67 & 22.79 & 18.43 & 5.62 & 3.25 & 3.53 & 1.63 \\
\hline $\begin{array}{l}\text { production factors } \\
\text { Countries oriented to }\end{array}$ & 54.46 & 58.05 & 30.85 & 27.24 & 9.17 & 8.73 & 5.52 & 5.99 \\
\hline 3. & $\begin{array}{l}\text { Countries oriented to } \\
\text { innovation }\end{array}$ & 40.56 & 40.49 & 40.59 & 38.80 & 11.06 & 12.12 & 7.79 & 8.59 \\
\hline 4. & The EU average & 39.10 & 36.07 & 38.58 & 40.95 & 13.38 & 12.88 & 8.95 & 10.1 \\
\hline 5. & Austria & $*$ & 34.11 & $*$ & 41.15 & $*$ & 14.30 & $*$ & 10.44 \\
\hline 6. & Belgium & 27.58 & 28.9 & 44.00 & 38.99 & 17.08 & 16.77 & 11.34 & 15.94 \\
\hline 7. & $\begin{array}{l}\text { Bosnia and } \\
\text { Herzegovina }\end{array}$ & 42.57 & 47.80 & 36.57 & 34.26 & 12.70 & 12.89 & 8.16 & 5.06 \\
\hline 8. & Croatia & 16.09 & 20.53 & 42.91 & 41.09 & 21.05 & 14.90 & 19.94 & 23.48 \\
\hline 9. & Denmark & $*$ & 70.7 & $*$ & 16.01 & $*$ & 7.23 & $*$ & 6.06 \\
\hline 10. & Estonia & 31.41 & 29.45 & 42.55 & 46.58 & 15.24 & 14.38 & 10.80 & 9.59 \\
\hline 11. & Finland & 59.03 & 54.95 & 29.98 & 32.16 & 6.99 & 2.63 & 4.00 & 10.26 \\
\hline 12. & France & 44.99 & 36.31 & 36.42 & 41.73 & 12.5 & 10.43 & 6.09 & 11.53 \\
\hline 13. & Greece & 44.32 & 41.78 & 42.59 & 41.73 & 6.07 & 6.54 & 7.02 & 11.18 \\
\hline
\end{tabular}


Helena Kościelniak

\begin{tabular}{|c|c|c|c|c|c|c|c|c|c|}
\hline \multirow{2}{*}{$\frac{\text { No. }}{14 .}$} & \multirow{2}{*}{$\begin{array}{l}\text { Country } \\
\text { Spain }\end{array}$} & \multicolumn{2}{|c|}{$\begin{array}{l}\text { Non- } \\
\text { exporters }\end{array}$} & \multicolumn{2}{|c|}{$\begin{array}{l}\text { Small-scale } \\
\text { exporters }\end{array}$} & \multicolumn{2}{|c|}{$\begin{array}{l}\text { Medium-scale } \\
\text { exporters }\end{array}$} & \multicolumn{2}{|c|}{$\begin{array}{l}\text { Established } \\
\text { exporters }\end{array}$} \\
\hline & & 72.79 & 67.57 & 17.94 & 18.87 & 4.44 & 7.17 & 4.84 & 6.39 \\
\hline 15. & Holland & 46.54 & 49.45 & 39.12 & 34.68 & 8.90 & 9.19 & 5.44 & 6.68 \\
\hline 16. & Ireland & 40.77 & 39.74 & 33.71 & 36.00 & 12.33 & 14.02 & 15.19 & 10.24 \\
\hline 17. & Lithuania & 30.85 & 24.70 & 43.17 & 52.14 & 17.10 & 14.36 & 8.89 & 8.80 \\
\hline 18. & Luxembourg & 11.75 & 4.13 & 54.29 & 54.03 & 19.32 & 25.09 & 14.64 & 16.76 \\
\hline 19. & Germany & 45.90 & 43.50 & 37.97 & 35.42 & 11.11 & 13.07 & 5.02 & 8.01 \\
\hline 20. & Norway & 60.33 & 67.27 & 23.14 & 22.73 & 7.44 & 6.36 & 9.09 & 3.64 \\
\hline 21. & Poland & 21.04 & 16.79 & 55.38 & 68.71 & 14.05 & 6.36 & 9.53 & 5.63 \\
\hline 22. & Portugal & 27.11 & 23.75 & 43.16 & 54.29 & 17.73 & 11.63 & 12.00 & 10.32 \\
\hline 23. & Russia & 91.34 & 90.34 & 3.01 & 4.82 & 1.05 & 1.13 & 4.6 & 3.71 \\
\hline 24. & Romania & 29.64 & 23.96 & 38.56 & 46.71 & 20.51 & 20.68 & 11.29 & 8.64 \\
\hline 25. & Slovakia & 12.92 & 14.49 & 65.94 & 66.18 & 15.18 & 13.04 & 5.96 & 6.28 \\
\hline 26. & Slovenia & 26.22 & 28.57 & 47.51 & 39.82 & 10.75 & 19.66 & 15.52 & 11.95 \\
\hline 27. & Switzerland & 19.34 & 28.89 & 52.88 & 40.10 & 20.37 & 21.22 & 7.41 & 9.78 \\
\hline 28. & Sweden & 42.90 & 33.56 & 34.95 & 39.08 & 12.57 & 13.20 & 9.59 & 14.16 \\
\hline 29. & $\begin{array}{l}\text { United States of } \\
\text { North }\end{array}$ & 15.16 & 16.34 & 73.57 & 69.14 & 9.58 & 9.14 & 3.77 & 5.38 \\
\hline 30. & Hungary & 36.83 & 32.86 & 40.97 & 43.81 & 16.32 & 15.73 & 5.89 & 7.60 \\
\hline 31. & United Kingdom & 62.13 & 60.45 & 21.1 & 24.66 & 9.09 & 8.75 & 7.68 & 6.14 \\
\hline 32. & Italy & 55.63 & 50.06 & 27.25 & 29.16 & 10.39 & 14.64 & 6.73 & 6.13 \\
\hline
\end{tabular}

*no data

Source: (GEM 2014; GEM 2015, p. 32-33)

In the countries based on production factors and oriented to efficiency, the percentage of non-internationalized enterprises rose respectively by 8.6 and 3.6 percentage points. In innovative countries, this percentage almost remained stable and, in the EU, it fell by 3 percentage points. Similar changes refer to the percentage of exporters, particularly low-scale ones; in less developed countries, the percentage fell by 4 percentage points whereas, in the whole EU, it rose by more than 2 percentage points. In innovative countries, this index decreased by more than 2 percentage points.

Making the assessment of internationalization at the level of individual countries, it should be stated that, in the analyzed period, there was an increase in non-exporters (the least favorable changes in the structure of enterprises) in such countries as: Norway by $7 \%$, Bosnia and Herzegovina by 5\%, Croatia by $4 \%$ and Holland by 3\%; the sharpest decrease of non-exporters was recorded in Sweden (more than 9\%), France (more than 8\%), Luxembourg (approximately 7.6\%), Spain (more than 5\%), Poland and Finland (more than 4\%). In Poland, there was an increase of more than $13 \%$ of exporters having up to $25 \%$ of their customers outside their home country among entrepreneurs at the early stage of development; in 2014 it amounted to about $69 \%$. The highest growth in medium-scale exporters was recorded in Slovenia (9\%), Luxembourg (6\%) and Italy (4\%). The group of enterprises having more than $75 \%$ of customers outside their home country and where there was an increase in this field in years 2013-2014 includes enterprises of 
the following countries: Finland (an increase by 6\%), France and Sweden (an increase by approximately 5\%), Croatia and Belgium (an increase by approximately $4 \%$ ).

In Poland, in years 2013-2014 there was a decrease in the number of medium-scale enterprises by about $8 \%$ and the established ones by about $4 \%$.

Summing up, it should be stated that, compared to the results of 2013, in Poland, there was a fall in the percentage of enterprises in two export-related specialized groups: medium-scale exporters and established ones.

A significant increase (by more than 13\%) in small-scale exporters indicates that some of exporters decreased the intensity of their export.

There should be pinpointed the fact of the decreasing share of enterprises in Poland that operate only on the domestic market (by more than $4 \%$ compared to 2013). The percentage of such enterprises is more than twice lower than the EU average.

The conducted research also includes intrapreneurship which may contribute to the development of the socio-economic level. The following four indices were used to measure intrapreneurship:

- the leading role in organizational entrepreneurship (activity within the last 3 years) among the population,

- the leading role in organizational entrepreneurship (activity within the last 3 years) among employees,

- the leading role in organizational entrepreneurship (present activity among the population),

- the leading role in organizational entrepreneurship (present activity among employees).

Table 4. The level of intrapreneurship in the European countries included by GEM in years 2011-2014

\begin{tabular}{|l|l|l|l|l|l|}
\hline \multirow{2}{*}{ No. } & Country & \multicolumn{3}{|l|}{$\begin{array}{l}\text { The leading role in } \\
\text { organizational entrepreneurship } \\
\text { (activity in years 2011-2013) } \\
\text { among: }\end{array}$} & $\begin{array}{l}\text { The leading role in } \\
\text { organizational entrepreneurship } \\
\text { (activity in years 2014) } \\
\text { among: }\end{array}$ \\
\cline { 2 - 6 } & the population & employees & \multicolumn{2}{|l|}{ the population } & employees \\
\hline 1. & $\begin{array}{l}\text { Countries oriented to } \\
\text { production factors }\end{array}$ & 1.3 & 4.5 & 1.1 & 3.6 \\
\hline 2. & $\begin{array}{l}\text { Countries oriented to } \\
\text { efficiency }\end{array}$ & 1.7 & 4.1 & 1.3 & 3.2 \\
\hline 3. & $\begin{array}{l}\text { Countries oriented to } \\
\text { innovation }\end{array}$ & 5.2 & 8.1 & 4.1 & 6.4 \\
\hline 4. & The EU average & 4.7 & 7.9 & 3.7 & 6.1 \\
\hline 5. & Austria & 5.6 & 10.0 & 4.3 & 7.5 \\
\hline 6. & Belgium & 5.4 & 8.5 & 4.0 & 6.3 \\
\hline 7. & $\begin{array}{l}\text { Bosnia and } \\
\text { Herzegovina }\end{array}$ & 1.9 & 5.5 & 1.7 & 4.9 \\
\hline 8. & Croatia & 3.6 & 8.4 & 3.0 & 6.9 \\
\hline 9. & Denmark & 11.4 & 16.8 & 8.6 & 12.6 \\
\hline
\end{tabular}


Helena Kościelniak

\begin{tabular}{|l|l|l|l|l|l|}
\hline 10. & Estonia & 3.6 & 5.4 & 2.9 & 4.3 \\
\hline 11. & Finland & 4.5 & 6.4 & 3.7 & 5.3 \\
\hline 12. & France & 3.8 & 6.3 & 2.6 & 4.4 \\
\hline 13. & Greece & 0.8 & 2.1 & 0.6 & 1.7 \\
\hline 14. & Spain & 1.8 & 4.8 & 1.5 & 3.9 \\
\hline 15. & Holland & 7.0 & 9.4 & 5.2 & 7.0 \\
\hline 16. & Ireland & 6.7 & 11.8 & 5.6 & 10.0 \\
\hline 17. & Lithuania & 5.1 & 10.2 & 3.4 & 6.7 \\
\hline 18. & Luxembourg & 7.3 & 10.7 & 5.1 & 7.5 \\
\hline 19. & Germany & 4.5 & 6.6 & 3.5 & 5.1 \\
\hline 20. & Norway & 7.9 & 9.9 & 5.4 & 6.7 \\
\hline 21. & Poland & 3.4 & 6.6 & 2.3 & 4.4 \\
\hline 22. & Portugal & 3.2 & 6.2 & 2.4 & 4.6 \\
\hline 23. & Russia & 0.5 & 0.8 & 0.4 & 0.6 \\
\hline 24. & Romania & 4.9 & 8.1 & 4.1 & 6.6 \\
\hline 25. & Slovakia & 4.9 & 8.4 & 4.3 & 7.4 \\
\hline 26. & Slovenia & 4.7 & 8.6 & 3.8 & 6.9 \\
\hline 27. & Switzerland & 6.1 & 9.4 & 4.9 & 7.6 \\
\hline 28. & Sweden & 5.8 & 8.1 & 4.7 & 6.6 \\
\hline 29. & Hungary & 2.8 & 5.8 & 1.8 & 3.8 \\
\hline 30. & United Kingdom & 7.0 & 11.2 & 6.2 & 9.9 \\
\hline 31. & Italy & 0.8 & 1.9 & 0.6 & 1.6 \\
\hline & & & & 5.0 & \\
\hline 32. & United States of & 6.5 & 10.5 & 0.1 \\
\hline & North1. & & & \\
\hline
\end{tabular}

Source: (GEM 2014; GEM 2015, p. 33-34)

The research results presented in Table 3 indicate that the highest level of organizational entrepreneurship occurs, for all the indices, in the countries oriented to innovation. In the case of the number of employees as the reference point, this difference is twice as much compared to the countries at the lower level of the economic development; in the case of the percentage of the population, it is three or four times the difference. In Poland, the level of intrapreneurship is rather high compared to other countries oriented to efficiency. The leading roles in organizational entrepreneurship within the last three years were played by $3.4 \%$ of the total number of those surveyed and 6.6\% among employees. In $20142.3 \%$ of the respondents played the leading role in the discussed scope and $4.4 \%$ among employees. In the presented assessment, the level of intrapreneurship is rather low; a few countries achieve the results lower than in Poland in this field. This situation is related to low innovativeness of the economy, which is associated with intrapreneurship. Starting new ventures, even in the framework of the existing organizations, is connected with the allocation of resources which are not available with low innovativeness. 
Some interesting data come from four-year study referring to the motivation for starting new businesses. In years 2011-2013 Poles more frequently set up businesses out of necessity. In 2014 this trend was reversed; $47 \%$ of entrepreneurs of young companies set up their businesses due to the perception of an opportunity and $37 \%$ - out of necessity. The motivation out of necessity is still a strong feature of Polish enterprises and it is by $14 \%$ higher than the EU average (see Table 5).

Table 5. The motivation for setting up new businesses among Polish entrepreneurs in years 2011-2014

\begin{tabular}{|l|l|l|l|l|l|}
\hline \multirow{2}{*}{ No. } & \multirow{2}{*}{ Specification } & \multicolumn{3}{|l|}{ Years } \\
\cline { 3 - 6 } & & 2011 & 2012 & 2013 & 2014 \\
\hline 1. & $\begin{array}{l}\text { Opportunity associated with making } \\
\text { improvements (\% TEA*) }\end{array}$ & 31.5 & 30.1 & 32.7 & 47.1 \\
\hline 2. & Necessity (\% TEA) & 47.6 & 40.7 & 47.4 & 36.8 \\
\hline
\end{tabular}

*TEA- Total early-stage Entrepreneurial Activity

Source: (GEM 2014; GEM 2015, p. 33-34)

The perception of business opportunities is different depending on the region. In Poland, there can be identified four groups of voivodeships, where the level of perception of business opportunities is similar; they include:

- Subcarpathian, Opole, West Pomeranian with the level of perception of opportunities amounting to $11.5 \%-12,5 \%$;

- Warmian-Masurian, Lublin, Lesser Poland, Łódź with the level of perception of opportunities amounting to $16 \%-18.2 \%$;

- Świętokrzyskie, Silesian, Greater Poland, Lubuskie, Kujavian-Pomeranian (20.2\%-22.85\%);

- Pomeranian, Lower Silesian, Masovian (22.5\%-26.8\%).

The above research results became the inspiration for conducting the pilot study referring to the motivation for setting up new businesses in the nearest region, i.e. among entrepreneurs of the Silesian Voivodeship. For the purposes of the assessment of the opportunities associated with making improvements, there was electronically distributed the questionnaire addressed to the entrepreneurs of the metal industry (small, medium and large) operating on the market in two time periods: up to 4 years and more than 4 years. The total number of the questionnaires amounted to 65 out of which there were 54 properly completed and returned ones. The structure of the surveyed enterprises concerning the period of the activity with the division into small, medium and large was identical; there was $50 \%$ of the enterprises operating for less than 4 years and 50\% operating for more than 4 years. The medium enterprises amounted to $69 \%$ of the total number of the companies, the large ones $-11 \%$, and the small ones $-20 \%$. To examine the strength and direction of the relationships between the analyzed variables, there was used the correlation analysis (see Table 6). 
Table 6. Strength of relationships between the tested variables in the production companies of the metal industry of the Silesian Voivodeship

\begin{tabular}{|c|c|c|c|c|c|c|c|c|}
\hline \multirow[t]{2}{*}{ No. } & & \multirow[t]{2}{*}{$\begin{array}{l}\text { Period of } \\
\text { activity }\end{array}$} & \multicolumn{3}{|c|}{$\begin{array}{l}\text { The leading role in } \\
\text { organizational } \\
\text { entrepreneurship (activity } \\
\text { in years 2014-2015) } \\
\text { among the population }\end{array}$} & \multicolumn{3}{|c|}{$\begin{array}{l}\text { The leading role in } \\
\text { organizational } \\
\text { entrepreneurship (activity } \\
\text { in years 2014-2015) } \\
\text { among employees }\end{array}$} \\
\hline & & & small & medium & large & small & medium & large \\
\hline \multirow{2}{*}{1.} & \multirow{2}{*}{$\begin{array}{l}\text { Opportunity } \\
\text { associated } \\
\text { with making } \\
\text { improvements } \\
(\% \text { TEA*) }\end{array}$} & \begin{tabular}{|l} 
up to \\
4 years
\end{tabular} & 0.37 & 0.89 & 0.55 & 0.36 & 0.80 & 0.53 \\
\hline & & $\begin{array}{l}\text { more than } \\
4 \text { years }\end{array}$ & 0.57 & 0.91 & 0.62 & 0.50 & 0.73 & 0.46 \\
\hline \multirow[b]{2}{*}{2.} & \multirow{2}{*}{$\begin{array}{l}\text { Necessity } \\
(\% \text { TEA*) }\end{array}$} & up to 4 years & 0.40 & 0.79 & 0.55 & 0.33 & 0.72 & 0.46 \\
\hline & & $\begin{array}{l}\text { more than } \\
4 \text { years }\end{array}$ & 0.51 & 0.92 & 0.59 & 0.43 & 0.70 & 0.55 \\
\hline
\end{tabular}

Source: Author's own study based on own questionnaire

The conducted research indicates that statistically important correlations occur between the indices of intrapreneurship and the indices determining motivation for setting up new businesses. The highest values of correlation coefficients proving strong relationship between organizational entrepreneurship and entrepreneurship out of necessity among the population occurred for medium enterprises operating for more than 4 years; such a situation referred to $92 \%$ of the analyzed enterprises. These are negative relationships and they mean that, for the enterprises of the metal industry in the examined region, there is the shortage of business opportunities. Some explanation of the observed situation can also be the fact that the significant share of entrepreneurship out of necessity is observed in the countries with low level of the economic development and it is associated with high employment; then, the level of intrapreneurship is low.

\section{Conclusions}

The conducted research indicated that, in the situation of Polish enterprises, there is an increase in the interest in the international activity among young enterprises operating for up to 3.5 year; there is a decrease in the percentage of enterprises that are not internationalized at all and there is an increase in the percentage of the small-scale ones. A disturbing phenomenon is a decrease in the share of more experienced young enterprises having more than a quarter of their customers abroad. In the group of the established enterprises, there is an increase in the number of the companies that are more experienced in export, the ones having more than $25 \%$ of their customers outside Poland. The motivation out of necessity is still a strong feature of Polish entrepreneurs and it is by $14 \%$ higher than the EU average. The intrapreneurship undertaken by the surveyed enterprises of the 
Silesian Voivodeship results from necessity and proves the shortage of business opportunities, also in the region under consideration.

\section{Literature}

1. Bressand A., Distler C. (1955), La planete relationnelle, Flammarion, Paris.

2. Czakon W. (2012), Sieci w zarządzaniu strategicznym, Wolters Kluwer, Warszawa.

3. Domański Cz. (2001), Metody statystyczne. Teoria i zadania, Wydawnictwo Uniwersytetu Łódzkiego, Łódź.

4. GEM (2014), Global Entrepreneurship Monitor - Polska 2013, PARP, Warszawa.

5. GEM (2015), Global Entrepreneurship Monitor - Polska 2014, PARP, Warszawa.

6. Jelonek D., Turek T. (red.) (2015), Kreowanie przedsiębiorczości. Perspektywa procesów i technologii informacyjnych, Wydawnictwo Wydziału Zarządzania Politechniki Częstochowskiej, Częstochowa.

7. Koźmiński A.K. (2004), Zarządzanie w warunkach niepewności. Podręcznik dla zaawansowanych, Wydawnictwo Naukowe PWN, Warszawa.

8. Niemczyk J., Stańczyk-Hugiet E., Jasińska B. (2012), Sieci międzyorganizacyjne. Współczesne wyzwanie dla teorii i praktyki zarządzania, C.H. Beck, Warszawa.

9. Oparaocha G.O. (2015), SMEs and International Entrepreneurship: An Institutional Network Perspective, "International Business Review", Vol. 24, Issue 5.

10. Ziółkowska B. (2013), Zarządzanie procesami tworzenia wartości w przedsiębiorstwie. Perspektywa wirtualizacji, Wydawnictwo Politechniki Częstochowskiej, Częstochowa.

\section{UMIEDZYNARODOWIENIE I INTRAPRZEDSIEBIORCZOŚĆ W DZIAŁANIACH PRZEDSIĘBIORCZYCH PRZEDSIĘBIORSTW UNII EUROPEJSKIEJ W BADANIACH EMPIRYCZNYCH}

Streszczenie: Celem opracowania jest ukazanie zakresu umiędzynarodowienia i intraprzedsiębiorczości przedsiębiorstw w UE i ocena pozycji polskich firm z tego zakresu. Dla osiągnięcia zamierzonego celu przedstawiono perspektywy analityczne przedsiębiorczości (wybrane zagadnienia) oraz zaprezentowano wyniki badań empirycznych na bazie raportu Global Entrepreneurship Monitor za lata 2012-2014 oraz badań własnych z 2016 roku. Wartość opracowania polega na ukazaniu porównań w perspektywie globalnej, a także porównań między poszczególnymi krajami w omawianym obszarze, których dopełnieniem są fragmentaryczne wyniki badań intraprzedsiębiorczości, motywu szansy i konieczności przedsiębiorstw województwa śląskiego.

Słowa kluczowe: przedsiębiorczość, umiędzynarodowienie, intraprzedsiębiorczość 